Ref: 17-194

\title{
Gary Becker's Economics of Population: Reproduction and Neoliberal Biopolitics
}

Jemima Repo

School of Geography, Politics and Sociology, Newcastle University, Newcastle Upon Tyne, United Kingdom

Politics, 40-42 Great North Road, Newcastle Upon Tyne, NE1 7RU, UK

jemima.repo@ncl.ac.uk

orcid.org/0000-0001-7598-6589

Biographical note: Jemima Repo is Lecturer in the Politics of Gender at Newcastle University and a Visiting Research Fellow at the University of Helsinki. Her research interests include feminist and gender theory, biopolitics, and the politics of population. Her book The Biopolitics of Gender (Oxford University Press, 2015) was awarded the 2017 International Studies Association Feminist Theory and Gender Studies Book Prize.

Funding details: This research was supported by the Academy of Finland under grant numbers 285830 and 268181.

Acknowledgements: I am very grateful to Derek Bell, Sydney Calkin, Martin Coward, Matt Davies, Mark Griffiths, Graham Long and Luca Mavelli for their thoughtful and constructive feedback on this manuscript. I also thank Caroline Battacharya for her research assistance. 


\title{
Gary Becker's Economics of Population: Reproduction and Neoliberal Biopolitics
}

\begin{abstract}
This article argues that the work of Chicago School economist Gary Becker's theory of fertility underpins contemporary rationalities of global population governance. Drawing on feminist critiques of biopolitics, the article proposes reproduction as a missing link that ties Becker's homo economicus to the aggregate question of population. It argues that Becker's work challenged macroeconomic theories of fertility by figuring reproduction, and hence population patterns, as governed by the personal utility-maximising decisions of individuals. It further examines how his approach to fertility inaugurated reproductive decision-making as a regulatory node of population quality, one also tied to a particular sex, race, and class politics. Finally, the article briefly analyses the relationship between Becker's contribution and today's focus on women's reproductive and productive decision-making in population governance in the context of development.
\end{abstract}

Keywords: Gary Becker; neoliberal biopolitics; reproduction; fertility; population; development

\section{Introduction}

The Chicago School economist Gary Becker is known as a key theorist of human capital, but in population research he is best known for developing a major new approach to demographic change. ${ }^{1}$ As the prominent demographer Ronald Lee wrote after Becker's death in 2014, 'Becker's approach to fertility and the family... ha[s] become central to the way scholars in all disciplines think about fertility transition' (2015, p, 74). This area of Becker's work has been overlooked in recent work on the biopolitical aspects of the neoliberal subject of homo economicus (e.g. Dean, 2015; Dilts, 2014, pp. 51-84; Feher, 2009; Harcourt, 2011, pp. 133-136). Given that Michel Foucault discusses Becker's economics of the family in his The Birth of Biopolitics lectures - the text that spurred widespread interest in neoliberal biopolitics - this oversight is somewhat surprising. To address this gap, this article examines Becker's economic theory of fertility as a key text for understanding the conceptualisation of population under neoliberal biopolitics. It does so by proposing reproduction as a missing link that ties Becker's homo economicus to the broader biopolitical question of population in its aggregate form. This allows for a clearer genealogical understanding of what makes contemporary population governance specifically neoliberal, while accounting for the sex, race and class politics propagated by it.

Becker stands out among neoliberal economists for his broad and sustained interest in fertility, the family, and the sexual division of labour, though they are rarely mentioned in prominent political economic histories of neoliberal thought (e.g. Amadae, 2016; Peck, 2010; Van Horn et al., 2013). Becker's work in this field was far from marginal; A Treatise on the Family $(1981)^{2}$ is his most cited work after Human Capital (1964) and when the Royal Swedish Academy of Sciences awarded Becker the Nobel Prize in Economics, they gave special mention to his work on the family. ${ }^{3}$ Treatise is often seen as the text that brought Becker's theory of fertility transition into the mainstream of demographic research. The theory, which applied microeconomics to demographic change, was debated fiercely by demographers for two decades after its initial publication in 1960 (e.g. Blake, 1968; Leibenstein, 
1974; Namboodin, 1972; Sanderson, 1976). Since A Treatise, however, it has been cited consistently by leading demographers and sociologists as foundational to post-transitional ${ }^{4}$ family and fertility economics since its publication (e.g. Easterlin et al., 1980; Esping-Andersen and Billari, 2015; Folbre, 1983; Lee, 2015). In short, Becker's work on the family has been hugely influential, especially in the field of demography.

Despite a growing interest in Becker and the politics of life in social theory, Becker's immense impact on demographic knowledge has also been overlooked in recent discussions on neoliberal biopolitics, to which the question of population is pivotal (e.g. Lemke, 2011, pp. 109-111; Newheiser, 2016). In this area, scholars have persuasively demonstrated the materialisation of Becker's rationality of human capital into a sexualised and racialised means of differentiating between, transforming, incentivising, or abjectifying certain populations perceived as lacking in human capital, such as the poor, the disabled, women, migrants, and refugees (Calkin, 2015a; Millei and Joronen, 2016; Mavelli, 2016; Wacquant, 2004), yet there remains little knowledge or discussion of Becker's theory of fertility.

In this article, I develop the genealogy of neoliberal biopolitics in three original ways. First, introduce Becker's key texts on the economics of fertility to the archive of the genealogy. Second, I argue that Becker's theory of fertility was more than a micro-level theory of reproduction - it was a new economic paradigm of demographic change based on a rational choice model of human behaviour. Becker's theory of fertility, I argue, serves as a link between the management of individual bodies through the discourse of homo economicus and biopower at the aggregate level of population. Third, I tie these genealogical observations to present day rationalities of population governance in the context of development, which I argue are heavily influenced by Becker's theory of fertility.

The article consists of four sections. The first section discusses the absence of the demographic question of population from recent debates on neoliberal biopolitics and proposes feminist readings of reproduction as a fruitful way of addressing this gap. The second section proceeds to an exposition of Becker's economic theory of fertility. It specifically focuses on his problematisation of fertility rates, his articulation of reproduction as utility maximisation, and his implicit normative assumptions about the sexual division of labour. The third part analyses the discourse of the 'quality' of children central to Becker's model of reproductive decision-making, and the economisation of human fitness along race and class lines. The fourth part addresses the mobilisation of Becker's ideas in global population policy in the early 1990s, where it converged with a discursive shift towards reproductive choice and empowerment discourses in response to postcolonial and feminist criticism of postwar population control in the Global South. Finally, the conclusion ties the discussion back to the broader question of population in neoliberal biopolitics.

\section{Neoliberal Biopolitics: Linking to Population through Reproduction}

The idea of 'neoliberal biopolitics' has been inspired largely by Foucault's lectures on neoliberalism, titled The Birth of Biopolitics, which are known to its readers for their focus on neoliberalism rather than biopolitics (e.g. Lemke, 2001). One of the most useful concepts to be developed from the lectures is that of 'neoliberal governmentality' (Foucault, 2008, 12), a political rationality that reorganises the 
state and society according to the logic of the market (Brown, 2005, p. 38). The concept of 'neoliberal biopolitics', however, derives from Foucault's posthumous interlocutors rather than Foucault himself, and is typically used to describe how the politicisation of life becomes intertwined with its economisation (Lemke, 2011, p. 116), for instance through the financialisation of life (Cooper, 2008, p. 10).

Foucault's exegesis of Gary Becker's theory of human capital has been an important reference point for analysing the relationship between neoliberal rationality and biopolitics (e.g. Bröckling, 2011, pp. 100-106; May and McWhorter, 2015, p. 251). According to Foucault, Becker reinstates homo economicus, originally the classical liberal economic subject of exchange, as as an 'entrepreneur of himself' that constantly 'invests' in her/his physical and mental skills and abilities in order to accrue human capital (Foucault, 2008, p. 226). At its heart is a reconceptualisation of human behaviour as driven by a series of cost-benefit calculations. This translates into a new biopolitical model that 'allows behaviour to be governed... by manipulating the choices available' (Newheiser, 2016, p. 4). Human capital is developed into 'the barometer of all life's activities' (Winnubst, 2013, p. 466), on the basis of which individuals are encouraged to self-optimise and self-care through cost-benefit calculations in all stages of life. As such, May and McWhorter describe Becker's brand of American neoliberalism as not only a theory of markets, but as 'a theory of living' (2015, p. 251). The longterm investment in the intellectual, physical and social skills of each individual - monetised as 'capital' - is deemed to yield pay offs in terms of health, pleasure and wealth. As a new order of knowledge or ontological logic of managing human behaviour (Alt, 2015, Joronen, 2014, p. 357), therefore, neoliberalism can be seen as 'paradigmatically biopolitical' (Newheiser, 2016, p. 9).

These studies powerfully convey the subtle anatomo-politics by which individuals are assumed to govern themselves by the logic of human capital. The aggregate problem of population, however, remains somewhat obscured. ${ }^{5}$ If the human capital approach encourages individuals to self-adjust or invest in their personal qualities and become 'abilities-machines' (Foucault, 2008, p. 229), how does neoliberal thought figure, to use Foucault's words, the 'species body', its 'propagation, births, mortality, the level of health, life expectancy and longevity, with all the conditions that can cause these to vary' (Foucault, 1981, p. 139), in other words, the characteristics, variables, and patterns of life that constitutes a 'population'?

To answer this question, I propose revisiting Foucault's argument about the place of sexuality 'at the heart of this economic and political problem of population' (1981, p. 25). Sexuality for Foucault occupied a critical place as the 'pivot of the two axes along which developed the entire political technology of life' (Foucault, 1981, p. 145). These were the 'anatomo-politics of the human body' that disciplined and optimised the capacities of the body into an efficient and economic machine, and the 'biopolitics of the population' concerned with the calculated management of phenomena specific to the life of the entire social body or its constitutive groups taken as whole (Foucault, 1981, pp. 139, 145-146). In addition, the administration of life through sexuality was articulated in conjunction with racial discourses that differentiated the population into sub-groups; those whose lives should be protected and reproduced, and those whose could be neglected or exposed to death in order to ensure the survival and purity of the species (Foucault, 1981, p. 149; Stoler, 1995, p. 11). 
Feminist discussions have further emphasised the significance of both biological and sexual reproduction within this critical sexual intersection. Reproductive sexuality was concerned with the regulation of both the reproductive and productive potential of the population (Repo, 2013), both as a threshold of procreation (e.g. Deutscher, 2012, p. 133), as well as the reproduction of social and economic relations. Lettow (2015, p. 268) contends that reproduction serves as a nodal point for not two, but all three biopolitical problems: the management of populations, the production of sexual difference and kinship relations, and racialisation. The birth of the idea of sexual reproduction, according to Lettow, propelled the development of a theory of sexually different yet reproductively complementary subjects. This sexual complementarity was tied to the imperative to reproduce the species or race. The feminist emphasis of sexuality and/or reproduction as a biopolitical hinge, therefore, not only reappraises the centrality of reproduction to the biopolitical, but also it reveals the interconnected formation of sexed, raced and classed biopolitical technologies (Balfour et al., 2016, pp. 113-5).

Foucault's analysis of Becker's family economics, including reproduction, in The Birth of Biopolitics lectures has also been of recent interest to feminist scholars. The discussion is brief, only four pages long (Foucault, 2008, pp. 229, 243-246), but in it Foucault highlights some of the key aspects of Becker's economics of the family: the rendering of the household a unit of production comparable to the firm, the family as a transmitter of human capital, and marriage as a contractual agreement that supplies beneficial outputs based on certain inputs of affection and time. These observations have served as crucial reference points for feminist problematisations of the neoliberal economisation of the household (Cooper, 2017) and the obfuscation of the split between the public and private, and production and reproduction (Brown, 2015, pp. 100-105).

Foucault also briefly discusses the American neoliberal (mainly Becker's) interest in birth rates in relation to human capital theory. Two paragraphs of the tenth lecture examine how 'the neoliberals turn to the study of the problem of the birth rate and try to analyse again the fact that wealthy, or wealthier families are clearly more Malthusian than poorer families' (Foucault, 2008, p. 244). According to Foucault, the American neoliberals explain the smaller size of wealthier families through the 'necessity to transmit a human capital to the children which is at least equal to that of the parents' (Foucault, 2008, p. 245) - this requires investments in time and money that only small families can afford. As a series of investments, the mother-child relationship is also reconfigured: maternal care is reconceived as an investment in time, and the quality of care translates into more human capital for the child (Foucault, 2008, p. 244-245). Foucault therefore recognises that for Becker, human capital formation was a much broader question than schooling or training; in order to foster the individual into an 'abilities-machine' (2008, p. 229), parents - especially mothers - had to invest time, care, and affection in their children in order to ensure their scholastic and physical development (2008: p. 243-244).

Foucault's reading is undoubtedly useful for feminist biopolitical critiques, as is demonstrated in recent analyses of the marketised reproductive rationality that underpins contemporary reprogenetics and reconciliation policies (McWhorter, 2010, p. 58; Repo, 2016, p. 30). Despite mentioning birth rate and kinship relations, however, Foucault never articulates the immense importance of Becker's economic approach to fertility for the rearticulation of the problem of population ${ }^{6}$. This gap gives rise 
to a number of critical questions: what is the place of reproduction in Becker's economic approach? If reproduction is the 'glue' binding together the control of bodies and populations in modern biopolitics, how does it operate in Becker's neoliberal biopolitics? What kinds of sexual and racial norms and subjectivities does it produce and how? To address these questions, the discussion proceeds with a re-reading of Becker's work on fertility in order to analyse his reconceptualisation of population and demographic change.

\section{Gary Becker's Economic Approach to Fertility}

Foucault's (2008, pp. 243-244) lectures give the impression that Becker introduced the questions of fertility and the family in the context of human capital theory. Indeed, the third and final section of Human Capital, a book usually associated with education and on-the-job training, is entirely devoted to discussion of fertility, marriage and the sexual division of labour. Human Capital, however, was first published in 1964 without any references to family. Becker's theory of fertility, and subsequent related papers - for instance his theory of the allocation of time in the family (on which his human capital theory also depends) - were nonetheless developed at the same time as he began his work on human capital in the early 1960s. With the momentum gained from the success of A Treatise on the Family, Becker finally integrated these two related strands of his work by introducing four new chapters on the family based on his previous work into the third edition of Human Capital, published in $1993 .{ }^{7}$ We can therefore say that although there are clear connections between his work on fertility/family and human capital theory, they were initially developed in the 1960s in separate yet parallel publications.

The crucial text for understanding Becker's development of his economic theory of fertility is his first article on the subject, 'The Economic Analysis of Fertility', where he problematised the inability of demographers to explain changes in fertility rates. It was published in 1960, four years before Human Capital and sixteen years before Treatise. In 2017, it stands as his tenth most cited article. ${ }^{8}$ The analysis below therefore prioritises Becker's 1960 article as a crucial site at which population first became problematised in neoliberal thought. I also make use of related works subsequent years on the allocation of time in the family (1965), the quantity and quality of children (Becker and Lewis, 1973), marriage (Becker, 1973), and altruism (1976a), culminating in A Treatise of the Family (1981). ${ }^{9}$

In 'An Economic Approach to Fertility,' Becker sought to construct a framework that could more accurately explain demographic change - a task in which demographers, in his view, had failed. As he stated in the first sentence of the article, 'the inability of demographers to predict western birth rates accurately in the postwar period has had a salutary influence on demographic research' (1960, p. 209). The fall in fertility rates during the 1930s followed by the baby boom in the post-war period had contradicted predictions about the demographic future of the West. According to the demographic transition theories of the time, demographic change progressed according to phases of industrialisation. In the first phase, pre-industrialised societies had high fertility rates coupled with high mortality rates. Technological advances in hygiene, heath care, and food supply in particular lowered mortality rates at the next stage of transition, but fertility rates remained high, inducing rapid population growth, as was seen in Europe during the Industrial Revolution. It was assumed that both 
fertility and mortality would stabilise once a society was fully industrialised. Yet, fertility declined at the end of the nineteenth century, and again during the 1930s and 1940s, only to increase again after the Second World War. By the 1960s, fertility started to decline again in most of the world (Connelly, 2008, p. 237). These continuing fertility declines and increases baffled demographers, who were compelled to replace Malthusian approaches with theories of demographic transition, but they inspired Becker to tackle the question of fertility through microeconomics.

Demographic change to some extent had always been treated as an economic question, starting from Malthus's principle of population, where he applied the law of supply and demand to food production and population: an increase in food supply led to an increase in fertility, and a decrease caused a decline. Becker acknowledged the Malthusian legacy in his work, stating that Malthus's 'famous discussion was built upon a strongly economic framework' (Becker, 1960, p. 209), which he aimed to generalise and develop. By contrast to Malthus's macro-level analysis, however, Becker proposed a bottom-up approach that focused on economic decision-making in the family. In it, production was not the ultimate agent of change. Rather, it was calculating individuals themselves. In suggesting this, Becker did more than rephrase the relationship between economic factors and population; he set a new ontological interrogative agenda for demography where human behaviour, in the form of rational decision-making, was the driver of population change, the hidden workings of which could be revealed through the application of economic methodology to human behaviour. The central argument of Becker's article was therefore the radical claim that fertility could be understood by applying the same supply and demand approach used to understand the price and quantity of consumer goods to human reproductive behaviour.

This was the economic 'approach' as he called it - based on the basic tenets of microeconomic price theory - that for Becker defined the true essence of economics (Becker, 1976b, pp. 3-5). Rather than being characterised by its most common subject matter, such as markets or production chains, Becker argued that economics as a discipline distinguished itself through its particular economic ontology of human behaviour. This 'approach,' as Becker clarified in his book An Economic Approach to Human Behaviour (1976b), held three basic assumptions: first, that human behaviour is utility maximising; second, that markets coordinate the actions of different participants so that their behaviour becomes mutually consistent; and third, that people have preferences that are stable over time. These three statutes of utility maximisation, market equilibrium, and stable preferences, Becker wrote, 'used relentlessly and unflinchingly, form the heart of the economic approach' (1976b, p. 5). The innovative potential of this approach was not lost on Becker, who stated that 'the economic approach is uniquely powerful because it can integrate a wide range of human behaviour' (1976b, p. 5). All aspects of human activity and existence could therefore be systematically subjected to economic analysis precisely because economics as a discipline was now defined by its ontology of human behaviour rather than its object. Reproduction therefore could be refigured as a utility-maximising decision exercised by individuals based on their personal preferences in the marketplace of choice, rather than, for instance, simply human instinct.

By problematising reproduction as one of the areas of human behaviour that was amenable to an economic approach, the 'Economic Analysis of Fertility' article also transformed the ontological conception of the child and the family or household. From the outset, Becker's first move was to 
theorise the child as a consumer good. Like any product in the marketplace, 'children are assumed to provide "utility" to their parents, mainly as 'a source of psychic income or satisfaction' 10 (Becker, 1960, p. 211), but also sometimes even 'money income' (1960, p. 210) if they go to work and earn wages for the family. Reproduction was therefore not cast in traditional normative terms as a moral or national imperative, biological destiny, or even as a social function, but rather in economically instrumental terms as a computational outcome of parental utility optimisation of children-as-goods.

The theorisation of reproduction as utility maximisation also assumed not only that all parents obtain psychic benefits from children, but also, in line with the economic approach, that all parents have a stable preference for children. All parents were therefore assumed to want children. In other words, like consumers, parents are not only assumed to intrinsically desire consumer goods/children, but are independent and rational agents of consumption/reproduction with total control over their expenditure/fertility. Thus, not only does the analogy of consumption detach the child from the generative, reproductive labour of women's bodies, pregnancy, and childcare by imaging children as readily available objects that simply appear, it also overlooks the new duties and responsibilities that parents, often mothers, must accept, while ignoring that unlike consumer products, children are not easily disposable.

Moreover, as demographer Judith Blake (1968) argued already in the late 1960s, children are also not normatively indifferent: far from a straightforward monetary transaction, there is often a great deal uncertainty involved in reproduction (unplanned pregnancies, infertility, coercion, violence), as well as social, political and religious norms and pressures that shape contextualised discourses of reproduction. In fairness, Becker was aware that he was in the business of producing simplified 'fictions' (cf. Becker, Ewald and Harcourt, 2011, p. 25). As he makes clear at the beginning of the article, the assumption that 'each family has perfect control over both the number and spacing of its births' was an attempt to 'simplify the analysis of this problem' of reproductive decision-making (1960, p. 210). Becker therefore was most likely aware that even in places where women have better knowledge of contraception, it could not be said that they had total control over their reproduction. Yet, in order to make the problem of fertility 'fit' his utility-maximising consumer-subject, the complexity that define real-life reproduction had to be purposefully set aside.

Becker's model of fertility decision-making based on simplified assumptions about reproduction was integral to being able to extend price theory to reproductive decision-making in the family. The number of children was treated as the result of the 'demand' for children relative to their 'cost' to parents, determined by 'a mix of various factors: income, child costs, knowledge, uncertainty and tastes' (1960, p. 231). Effectively, the number of children in a family depended on how much families could afford to spend on them - in other words, their 'cost' or 'price' both in terms of income and time. As Becker (1960, p. 231) wrote:

In principle the net cost of children... equals the present value of expected outlays plus the imputed value of the parents' services, minus the present value of the expected money return plus the imputed value of the children's services. 
Conceptually and causally rethinking the determinants of fertility through the principle of supply and demand, the more expensive children were, the lower the fertility rate because of a subsequent fall in the 'demand' for children.

Becker further developed the idea of the price of children in his 1965 article 'A Theory of the Allocation of Time' through a reconceptualisation of the household. He argued that the household could be compared to 'a small factory' (1965, p. 496) because 'it combines capital goods, raw materials and labour to clean, feed, procreate and otherwise produce useful commodities' (1965, p. 496). In this theory, known as household production theory or new home economics, the household no longer consumes market goods and services, but rather the household itself is a producer of basic non-purchasable household commodities - that is, children who are consumed by parents/family who, in turn, create the demand for them. The household, the family, and children therefore operate in a closed economy of supply, demand, production and consumption.

The frequency of this production is grounded in a sexual division of labour that is regulated mainly through the distribution and use of labour-as-time in the family. Becker argued that time, as a scarce resource, was one of the key 'costs' relative to household income and time and other investments required for the production and care of children calculated by parents in their reproductive decisionmaking. Underlying the discourse of time, however, was the problematisation of women's reproductive and productive labour. Becker relied heavily on his Chicago colleague Jacob Mincer's (1962) study on the labour-force participation of married women, in which he argued that wives weighed the benefits of fertility against potential foregone wages if they, as wives, chose childbearing over paid employment. Becker used Mincer's work to argue that child care in particular was both a 'time-intensive activity' and an 'earnings-intensive activity' (1965, p. 510) since it requires losing wages that would otherwise be earned at work. In A Treatise on the Family, Becker stated even more explicitly that 'the growth in the earnings and labour force participation of women have been important causes of the significant decline in fertility since $1957^{\prime}$ (1981, p. 352). Dismissing any possible influence of changing social norms or feminism ${ }^{11}$, he argued that the increase in women's earnings and labour force participation had also decreased the 'gain from marriage' because it made the sexual division of labour 'less advantageous', thus also making divorce more 'attractive' (Becker 1981, p. 353) and procreation even less likely. In short, for Becker, women's increased participation in the labour force, and especially the choice to do so, were the main cause of declining fertility, and later also the decline of the nuclear family.

By treating women's labour force participation as a demographic 'problem,' Becker both idealised the traditional sexual division of labour and framed reproductive choice as comparable to any other form of labour market choice. Becker argued in Treatise that the sexual division of labour exists because it is the most profitable and 'efficient' form of time allocation: 'women have a comparative advantage over men in the household sector when they make the same investments in human capital' (1981, p. 38) whereas men are 'relatively more efficient at market activities' (1965, p. 512). He explained that nuclear families were the result of the historical development towards the most efficient family form. Single-headed households were a minority because 'households with men and women are more efficient than households with only one sex' (1981, p. 39). Moreover, the sexual division of labour in nuclear families was another result of historical utility maximisation. Men 
laboured in the market because they were better at maximising market efficiency, and women in the home because they specialised in household efficiency. This in turn 'reinforc[ed] any biologically induced sexual division of labour' (1981, p. 39) between them such as women's 'biological commitments to the production and feeding of children' (1981, p. 38). Therefore, in a tautological conclusion, because the economic approach is foregrounded on the assumption that the status quo has been historically shaped through individual utility maximisation, the dominance of the nuclear family could logically be nothing else than the outcome of the endeavour to produce utility as efficiently as possible.

As I have discussed so far, Becker's problematisation of declining fertility was central to the formation of microeconomic knowledge of reproduction, and subsequently, of children, parent-child relations, the household, and its sexual division of labour. These were refigured through Becker's economic approach to human behaviour to forge a new means of interpreting aggregate demographic data. The theory of time allocation enabled a focus on the productive and reproductive choices of women as a central demographic problem. The question of the quality of children, however, was also an essential part of Becker's reproductive epistemology, the race and class politics of which I examine in the following section.

\section{Race, Class and Population Quality}

Becker considered his treatise on quality as one of the key contributions that his economic framework had to offer the study of fertility. He felt that 'mutual interaction of quantity and quality... has been neglected all too often in writings on both population and on the quality of the labour force' (Becker, 1960, p. 229). This section of the article therefore discusses Becker's quantity-quality trade-off in relation to fertility transition. In particular, it focuses on his equation of better 'quality' children with the reproduction of the white middle class and its way of life. The quantity-quality calculus of reproduction is therefore the surface through which race and class become inscribed into Becker's neoliberal biopolitics.

Becker argued that the number of children in a family involved a 'quantity' versus 'quality' trade-off that increasingly came down on the side of quality in more industrialised societies. This, he stated, was because development increased the 'cost' of children, thus lowering the demand for their quantity and prompting parents to invest more in their quality. Once a family started to invest in the quality of the child, each child became more expensive and therefore provided diminishing returns in terms of utility. Fertility would therefore decline - just as the consumption of consumer products falls when prices increase - because people preferred to have fewer better quality children/products than many of poorer quality (Becker, 1960, pp. 211, 231).

To illustrate his analogy, Becker suggested that children were like cars that came in different qualities and therefore different prices: 'I will call more expensive children "higher quality" children, just as Cadillacs are higher quality cars than Chevrolets', Becker (1960, p. 211) stated. Pre-empting criticism for the comparison, Becker explained that: 
To avoid misunderstanding, let me hasten to add that 'higher quality' does not mean morally better. If more is voluntarily spent on one child than on another, it is because the parents obtain additional utility from the additional expenditure and it is this additional utility which we call higher 'quality' (1960, p. 211).

'Quality' therefore referred to the level of investment into the child's personal, physical, social, and intellectual qualities - what Becker and his colleagues would soon after call 'human capital' (Becker, 1964, Schultz, 1961). This additional time and money was spent on ensuring that children were 'better fed, housed, and clothed' (Becker, 1960, p. 214) and provided with 'separate bedrooms, send[ing] them to nursery school and private colleges, giv[ing] them dance or music lessons, and so forth' (1960, p. 211). Becker therefore equated 'quality' not only with meeting the basic needs for life and health, such as clothing, food and shelter, but in citing pre- and private school attendance and participation in costly extracurricular activities, 'quality' was synonymous with the ability of families to transmit to their children the habits, knowledge, networks, and skills of white post-war middle-class life, the realisation was dependent on the mother's use of time.

The assumption of white middle-class way of life as the guiding norm through which life quality is measured is also detectable in Becker's theory of the allocation of time, most likely due to its origins in Mincer's aforementioned 1962 study. Mincer argued that married women worked less if their husbands earned more, but worked more if women themselves earned more. The study, however, only examined 'white husband-wife families,' where the head of the family (i.e. the husband) was 'gainfully employed' (Mincer, 1962, p. 76). In his critical commentary on Mincer's article, economist Clarence D. Long remarked that, unlike white wives, black wives' labour force participation did not increase despite wage increases, challenging the generalisability of Mincer's results (Long in Mincer, 1962, p. 103-4). ${ }^{12}$ Because Becker's theory of the cost of children was dependent on the generalisability of Mincer's claim that women's earnings increased employment and therefore led to a decline in fertility because children became more 'expensive,' Becker's theory of fertility is also premised on a limited analysis of white married women's employment in 1960s America. More importantly, it exposes that it was the reproductive and productive 'choices' of the white, married, middle-class woman that were identified as 'problems' to be examined in Mincer's and Becker's work. This contrasts starkly to assumptions made about poor black women's reproduction in the 1960s, whose reproduction in itself was seen as problematic, with little interest in their reproductive 'preferences' or 'choices'. Indeed, with the introduction of the pill in 1960, white women became subjects of reproductive choice, while black women could be forcibly sterilised without their consent (e.g. Roberts, 1997, pp. 89-91). Whose choice-making mattered therefore mirrored the raced and classed reproductive politics of the post-war United States.

Becker, we can therefore say, abstracts away particular aspects of US society in order to assert a 'discovered ontological unity' (Clarke and Walsh, 2013, p. 349) of the social field even if it meant ignoring evidence to the contrary. The consequence would be the emergence of a new measure for population quality based on the habits, consumption, and structure of the white, middle class, married, nuclear family. If quality of the human population was secured biologically through eugenic social and medical programmes earlier in the century, in Becker's framework this quality becomes the automated outcome of the white, rational, middle- to high-income family, realised through a series 
of calculated choices regarding reproduction, care, housing, recreation and education. Ensuring the quality of children through optimised reproduction and care was important for guarantee a highquality labour supply in the future. As Becker writes:

The quality of children is very important in its own right, for it determines the education, health, and motivation of the future labour force. It is a major contribution of an economic framework to bring out the mutual interaction of quantity and quality - an interaction that has been neglected all too often in writings both on population and on the quality of its labour force. (1960, p. 229)

The question of quality was being developed in parallel emerging work by him and his colleagues at the University of Chicago in the field of human capital, which would become increasingly teleological in character. As Theodore W. Schultz wrote in his article Investment in Human Capital published a year later in 1961, direct investment in education, health, and leisure time to improve skills and knowledge were 'ways [in which] the quality of human effort can be greatly improved and its productivity enhanced', potentially leading to 'increases in national output' (1961, p. 1). In his 1982 book Investing in People: The Economics of Population Quality, Schultz would link the question of human capital to development, arguing that population quality via investing in the human capital (i.e. skills and knowledge) of poor people of colour was the most important untapped resource of aid agencies. The 'quality' of these individuals was integral to their efficient 'insertion of bodies into the machinery of production' as described by Foucault (1981, p. 141). But, rather than a controlled insertion, it was one that was self-controlled through the individualised reproductive calculations of the household unit based on the effective allocation of time among its members (i.e. the sexual division of labour). Better population 'quality' was an outcome belonging to the sexually stratified and financially equipped family that would make investments in their children's human capital, i.e. to provide their children with both the necessities and amenities of life and leisure to produce well-rounded, resourceful, and productive individuals.

In sum, therefore, reproductive decision-making was an automated regulator of population quality: those with more human capital would produce fewer but higher quality children, those with less were likely to produce more but lower quality children. While Becker refrained from speculating on the policies that enacted shifts between the two, he laid the theoretical and conceptual groundwork for considering the women's reproductive decision-making processes through the utility maximization theorem, tied to a teleology of population quality around the notion of human capital. In the next section I discuss how these two factors converged in 1990s population governance in the context of development.

\section{Governing Reproductive Choice: The Neoliberal Biopolitics of Population in Development}

To understand how Becker's theory of fertility ties homo economicus to the aggregate question of population under neoliberal biopolitics, this section discusses how Becker's approach to fertility has shaped population governance in the context of development. The role of Becker's theory of human capital in neoliberal development policy, where 'investing' in girls' education is seen as a guarantee to a better future, has been tackled in emerging feminist scholarship (e.g. Calkin 2018; Murphy, 
2017, pp. 115-116). This section clarifies the parallel importance of Becker's theory of fertility to population and development policy. The discussion is brief and therefore necessarily selective due to space limitations, but nonetheless aims to make some key connections between Becker's work and contemporary population policy prescriptions. I argue that first, population governance today aims to reduce fertility by governing women's reproductive decision-making, rather than direct control of their bodies. Second, investment in women's human capital is offered as a tool for intervening in women's reproduction and productive decision-making by 'freeing up' (Becker in Becker, Ewald and Harcourt, 2011, p. 17) their pool of choices. Finally, this reproductive/productive self-governance is framed as a pre-requisite for economic growth. In short, Becker's theory of fertility is a crucial framework underpinning the problematisation of women's reproductive and productive decision-making in the contemporary neoliberal biopolitics of population in development.

Texts on human capital since the 1960s, spearheaded especially by Becker and Schultz, were preoccupied with developing the teleological argument of human capital as key to economic growth and well-being, with a focus on education and training. As mentioned, it was not until the 1990s that Becker and his colleagues merged their research on fertility and the family with the theory of human capital. In 1990, Becker, with Kevin M. Murphy and Robert Tamura, published an article titled 'Human Capital, Fertility, and Economic Growth,' ${ }^{13}$ which argued for the central role of human capital in moving economies out of the so-called "undevelopment "trap" (Becker, Murphy and Tamura, 1990, p. S32) towards development and economic growth. Crucially, it also extended Becker's work on fertility from the 1960s to development, arguing that as wages increased owing to human capital investment, married women were likely to spend more time in the labour force than at home, hence weakening the sexual division of labour and lowering fertility. T. Paul Schultz, an economist who since the 1960s had developed Becker's theory of fertility in relation to women's time allocation in low-income countries, then connected human capital to fertility and growth as we know it from development discourse. ${ }^{14}$ Forging a crucial biopolitical link between human capital on the one hand, and fertility and economic growth on the other, T. Paul Schultz argued that increasing the schooling of women is the best predictor for reducing fertility and curbing population growth' (1994, p. 260). Investment in human capital was lifted up as the key intervention that could appropriately adjust the kinds of reproductive and productive decision made by women.

The emergence of women's human capital as a prominent development policy area is, of course, not attributable solely to Becker. Rather, Becker's ideas became timely in the 1990s following two decades of changes in the development field, especially with regards to women's role in development. Women's reproduction has been a priority in the biopolitics of development since the postwar period. Until the 1970s, women were seen as largely irrelevant to development outside their roles as biological reproducers of 'excess' populations threatening to set off what Paul R. Ehrlich famously called a 'population bomb'. Thus, in the first decades of the postwar era, Western population control programmes targeting women's reproduction in the Global South consisted of coordinated efforts to persuade women to reduce their fertility through contraception, abortion and sterilisation, also by forced or coercive means (Wilson 2015). In the 1970s, however, women's place in development began to change. For example, Ester Boserup's pioneering 1970 book Women's Role in International Development argued that 'the recruitment of women to the modern 
sector helps to accelerate the growth of the economy beyond the rate attainable by the use of male labour alone' (Boserup, 1970, p. 199), introducing a new approach to Women in Development (WID) that recognised the economic potential of women's contributions to production. ${ }^{15}$ The 1974 UN World Population Conference in Bucharest can be seen as a key moment when the population control movement was delegitimised, owing to widespread criticism of its women's rights abuses and neo-colonial character by women and people of colour (Connelly, 2008, p. 310-7). Edging towards a late capitalist governmentality that promoted self-governance over disciplinary practices (Rose and Miller, 1990, pp. 18-22) as well as the neoliberal appropriation of feminist discourses about reproductive 'choice' (Wilson, 2015, p. 815), the 1974 Conference also featured the beginnings of a new agenda for population governance that focused on 'women's status' and the right of individuals to determine the size of their own families.

The relevance of the work Becker and his interlocutors must be considred with these political dynamics in mind. Writing against a backdrop where women were starting to be seen as assets of development, the notion of women as rational, decision-making actors offered a scientific approach to population and development governance that accommodated feminist demands for women (especially women of colour) to be seen as agents with rights over their own bodies, rather than objects to be controlled. The field developed rapidly, also drawing on and subsuming previous studies of the links between women's education, fertility and economic development under the rubric of 'human capital'. T. Paul Schultz's 1995 edited book, Investment in Women's Human Capital, featuring prominent economists such as Boserup herself, is a case in point.

By the 1994 World Population Conference in Cairo, women's reproductive choice-making, and its governance, was affirmed as the new core of population and development programmes. As conference report states:

Improving the status of women also enhances their decision-making capacity at all spheres of life, especially in the area of sexuality and reproduction. This, in turn, is essential for the long-term success of population programmes. Experience shows that population and development programmes are most effective when steps have simultaneously been taken to improve the status of women. (United Nations, 1995, p. 22).

Reducing fertility therefore continued to be treated as a necessity for development, but now through strategies that took the improvement of women's decision-making abilities as their primary target. The reproductive control programmes of the past were largely no longer justifiable, nor were they seen as necessary, when women were assumed to prefer fewer children given the option. Women's autonomy could therefore be framed as biopolitically beneficial, even essential, for economic growth. Thus, to continue to exercise control over women's bodies, women's choices became the new target of biopolitical intervention. ${ }^{16}$

As feminist scholars have argued, one the main problems with the idealization of women's agency as the go-to solution to development is its obfuscation of alternative explanations and approaches, for instance those that offer historically embedded global power structures as the cause of poverty and exploitation (e.g. Calkin, 2015b; Koffman and Gill, 2013; Roberts, 2015; Shain, 2013). Most 
recently such approaches have translated into a call for greater equality for the girl child in development institutions. As a result, the (poor, non-Western) 'Girl' has become the darling of development discourse and is paradigmatically biopolitical. As Koffman and Gill (2013, p. 95) argue, discourses around the Girl mobilise this explicit link between empowerment, fertility and economic prosperity. In line with Becker's reasoning, adolescence is seen as a crucial period of human capital formation. In order to get the best possible returns on her future earnings, and produce an 'idealised neoliberal subject who can negotiate unfettered and unregulated markets with ease' (Wilson, 2015, p. 819) while simultaneously making responsible reproductive decisions, development institutions aim to make initial interventions before girls reach the age of reproductive and productive maturity. By making girls better managers of their reproduction and production, they are expected to lower fertility and increase women's wage earnings potential, which, as Becker argues, is key to further fertility decline. In turn, these measures were expected to country's overall GDP per capita (Murphy, 2017, p. 113). The turn to girls can therefore be seen as the attempt to regulate the reproduction and production of populations of the Global South in even more efficient and cost-efficient by intervening early into the female life cycle, while obscuring the economic and political structures that sustain North-South inequalities.

\section{Conclusion}

Understanding Becker's economics of reproduction matters because it informs the knowledge and governance of populations today. In the 1960s and 1970s, leading demographers either approved of his theory and started to apply it in their own research (e.g. Easterlin, 1966; Freedman and Coombs, 1966; Spengler, 1966), or condemned it as de-humanising, criticising Becker's methodology and its disregard for social context (e.g. Blake, 1968). Today, Becker's theory is celebrated across the subdisciplines of demography, from sociology (Esping-Anderson, 2015) to economic demography (Pollak, 2003, p. 112) as a founding contribution to contemporary demography. Becker's economic ontology of reproductive life underpins not only utterances in everyday life, from the idea of children as something that parents can or cannot 'afford', to the idea of the 'marriage market'. It defines the problems and solutions proposed in global population governance and development, where women's decision-making is targeted as a means to regulate fertility and encourage economic growth.

Taking account of Becker's approach to fertility in the genealogy of neoliberal biopolitics shifts our understanding of the global biopolitics of postwar population governance. Without it, it is impossible to understand how population in its aggregate form and its particular phenomena are conceptualised and governed under neoliberal rationality. Similarly, without a grasp of the economization of reproductive sexuality under neoliberal thought, the ways in which sexual relations, kinship and social reproduction are re-mobilized to create and insert bodies into an efficient economic machine would remain obscured.

As a harbinger of our twenty-first century ontology of reproduction, Becker introduced the idea of reproduction as a matter of utility maximisation. Reproduction - its relations, practices, and institutions - shifted from being a medicalised domain of knowledge that called for interventionist control, to being a behavioural result of the personal decisions of individuals that required the promotion of self-regulation via decision-making. The trade-off between the 'quality' and quantity 
of children became the calculative nexus through which population trends took shape, also producing populations of higher or lower quality.

Becker therefore introduced a distinctively neoliberal approach to population. His theory challenged previous macro-economic theories of fertility transition based on stages of industrialisation and supplanted it with a theory that assumed human reproductive behaviour to operate on the basis of supply-and-demand microeconomic principles. The aggregate question of birth rates became a variable that hinged on an assumed individual drive for utility optimisation. For Becker, economics was a wide-ranging scientific method for capturing how the aggregate biological patterns of population are determined by individual utility maximisation. Economic abstraction was therefore not just a means of mapping demographic trends and probabilities (Porter, 1986, pp. 50-51), but one of revealing the personal calculative psychology of individuals through which demographic equilibrium was achieved.

My core argument is therefore that Becker's work has significantly contributed to the formation of a neoliberal biopolitics that governs populations through the management of individual decisionmaking, where women's reproductive and productive choices are understood as the key targets of intervention for governing both population size and economic growth. Reproduction, we can therefore conclude, prevails as a critical biopolitical hinge of Beckerian neoliberal biopolitics. It forms a bridge between the individual project of the homo economicus to improve one's human capital on the one hand, and a biopolitics of population framed as the collective outcome of the strategic choice-making of individuals. Recalling Lettow's (2015) analysis of reproduction as a nodal point for the three biopolitical problems of population, sexual difference, and racialisation, in Becker's approach to reproductive 'choice' also unfolds in the context of global population governance as the threshold through population quality (defined in terms of white, Western, heterosexual, middle-class norms) is ensured.

Because of implications the theory of fertility has for biological and social reproduction, Becker's theory of fertility can also be seen as conductor of the expansion of neoliberal rationality into other aspects of sociological knowledge and life. It is a gravitational centre around which a host of spaces, relationships, practices and institutions such as the household, family relationships, child care, health, and education become viable objects of economic knowledge. This research therefore presents numerous avenues for further research, such as further examination of the integration of the Beckerian framework by demographers and sociologists, and into policy. The above account of global population governance is indicative rather than exhaustive. At the very least, this brief genealogy may help with subsequent endeavours to critically engage with contemporary neoliberal biopolitics.

\section{Endnotes}

${ }^{1}$ Becker's contribution to postwar demographic politics has been overlooked in the critical literature on population politics, most likely because it emerged from demographic debates on declining fertility in the West, whereas histories of global postwar population governance usually 
chronicle Western fears of overpopulation in the Global South, often focusing on the geographically uneven sexual and racial politics of birth control (e.g. Bashford, 2014; Connelly, 2008).

2 The book took Becker, by his own account, six years to write and left him 'exhausted' and needing 'roughly two years to regain [his] mental energy' (Becker, 2009, p. 266).

${ }^{3}$ See Royal Swedish Academy of Sciences (1992). Responding to the Nobel Committee's characterisation of his work as 'controversial and hence, at the outset met with scepticism and even distrust', Becker conceded that 'nowhere has this characterisation been truer than with my work on the family' (Becker, 2009, p. 266).

${ }^{4}$ A 'post-transitional' society is characterised by low fertility and low mortality rates.

${ }^{5}$ One notable exception is the work of Luca Paltrinieri (2017), who has compared Malthus and Marx's economic concepts of population with that of Gary Becker. Unlike previous scholars, Paltrinieri recognises Becker's achievement of producing a 'new demographic economics' that introduced a novel causal explanation for demographic change that likened fertility choices to consumer choices. As Patrinieri's study constructs a genealogy of the relationship between economics and population, my work contributes to this discussion by examining of the place and significance of reproduction in Becker's economics of population.

${ }^{6}$ Of course, due to the exploratory and remarkably anticipatory nature of the lectures, it is difficult to blame Foucault for this oversight.

${ }^{7}$ Becker also added a separate section on 'Human Capital and the Family' to the first substantial chapter "Human Capital Revisited" (1993, pp. 17-20).

${ }^{8}$ The economic approach to the family was also developed by his colleagues Jacob Mincer and Theodore W. Schultz. Mincer's work (1962; Mincer and Polachek, 1974) mainly focused on the impact of women's earnings on labour force participation and the sexual division of labour, rather than fertility and population. Schultz $(1973 ; 1974)$ developed the theoretical relationship between fertility and human capital in his later work, which largely building on Becker's work and leaving its basic theoretical argument unchallenged.

${ }^{9}$ Becker republished most of these articles in his book The Economic Approach to Human Behaviour (1976b). Its core ideas are reiterated in A Treatise on the Family (1981).

${ }^{10}$ The 1960 article does not yet explicitly ascribe the 'psychic income' gained from reproduction to mothers.

${ }^{11}$ Becker believed that the women's movement was 'primarily a response to other forces that have dramatically changed the role of women rather than a major independent force in changing their role' (1980, p. 356), reducing it to a form of 'emotional support' that followed, rather than caused, social change.

${ }^{12}$ Black women in the US were more likely to maintain households alone, and their labour force rates remained stable at around 40\% (see Nicholson, 2008, pp. 162-3).

13 The essay was first published in a special issue in Journal of Political Economy in 1990, and in 1993 integrated into the third edition of the Human Capital book.

${ }^{14}$ T. Paul Schultz was one of the earliest population economists to take up Becker's approach. At the RAND Corporation between 1965 to 1972, during which time he was founded and led its Population Research Program (now known as the Labor and Population Program), Schultz published several papers, often sponsored by USAID and the Rockefeller Foundation, examining the influence of women's economic opportunities on their allocation of time and, hence, their fertility (e.g. 1967, 1969, 1974).

${ }^{15}$ Boserup's book also provided fertile ground for feminist critiques of development practice with the observation that women largely pay the price of modernisation, for instance by reducing their access to productive work through technologisation, the masculinisation of the urban workforce, and the limiting of access to financial resources to men as 'heads of household'.

${ }^{16}$ This is not to say that methods of direct bodily control, even coercive ones, have disappeared. Rather, they continue to co-exist alongside neoliberal 'empowerment' policies. 


\section{References}

Alt, S. (2015) Beyond the Biopolitics of Capability and Choice in Human Development: Being, Decision, and World. Millennium, 44 (1), 69-88.

Amadae, S.M. (2016) Prisoners of Reason: Game Theory and Neoliberal Political Economy. Cambridge: Cambridge University Press.

Bashford, A. (2014) Global Population. History, Geopolitics, and Life on Earth. New York: Columbia University Press.

Balfour, L., Falguni A. S., Fogg Davis, H., Threadcraft, S., \& Repo, J. (2015) Bodies in Politics. Contemporary Political Theory, 15 (1), 80-118.

Becker, G. (1960) An Economic Analysis of Fertility. In National Bureau of Economic Research (Ed.), Demographic and Economic Change in Developed Countries (pp. 209-40). Princeton: Princeton University Press.

Becker, G. (1965) A Theory of the Allocation of Time. The Economic Journal, 74 (299), 493-517.

Becker, G. \& Lewis, Gregg H. (1973) On the Interaction between the Quantity and Quality of Children. Journal of Political Economy, 81 (2), 279-288.

Becker, G. (1973) A Theory of Marriage: Part I. Journal of Political Economy, 81 (4), 813-846.

Becker, G. (1976a) Altruism, Egoism and Genetic Fitness. Journal of Economics Literature, 14 (3), 817-826.

Becker, G. (1976b) The Economic Approach to Human Behaviour. Chicago: Chicago University Press.

Becker, G. (1981) A Treatise on the Family. Cambridge: Harvard University Press.

Becker, G. (2009) Gary S. Becker. In R. W. Spencer and D. A. Macpherson (Eds), Lives of the Laureates (pp. 251-272), $5^{\text {th }}$ ed. Cambridge: MIT Press.

Becker, G. (1993) [1964] Human Capital: A Theoretical and Empirical Analysis with Special Reference to Education: Third Edition. Chicago: Chicago University Press.

Becker, G., Ewald, F. \& Harcourt, B. (2011) Becker on Enwald on demograp on Becker. The Carceral Notebooks, 7, 1-35. 
Becker, G., Murphy, K. M., Tamura, R. (1990) Human Capital, Fertility, and Economic Growth. Journal of Political Economy, 98 (5), S12-S37.

Blake, J. (1968) Are Babies Consumer Durables? A Critique of the Economic Theory of Reproductive Motivation. Population Studies, 22 (1), 5-25.

Boserup, E. (1970) Women's Economic Role in Development. London: George Allen and Unwin.

Bröckling, U. (2011) Human Economy, Human Capital: A Critique of Biopolitical Economy. In U. Bröckling, S. Krasmann \& T. Lemke (Eds), Governmentality: Current Issues and Future Challenges (pp. 247-268). London: Routledge.

Brown, W. (2005) Edgework: Critical Essays on Knowledge and Politics. Princeton: Princeton University Press.

Brown, W. (2015) Undoing the Demos. New York: Zone Books.

Calkin, S. (2015a) 'Tapping' Women for Post-Crisis Capitalism. International Feminist Journal of Politics, 17 (4), 611-629.

Calkin, S. (2015b) Post-Feminist Spectatorship and the Girl Effect: 'Go Ahead, Really Imagine Her' . Third World Quarterly, 36 (4), 654-669.

Calkin, S. (2018) Human Capital in Gender and Development. London: Routledge.

Clarke, S. and Walsh, A. (2013) Imperialism, Progress, Developmental Teleology, and Interdisciplinary Unification. International Studies in the Philosophy of Science, 27 (3), 341-351.

Connelly, M. (2008) Fatal Misconception: The Struggle to Control World Population. Cambridge: Harvard University Press.

Cooper, M. (2008) Life as Surplus: Biotechnology and Capitalism in the Neoliberal Era. Seattle: University of Washington Press.

Cooper, M. (2017) Family Values: Between Neoliberalism and the New Social Conservatism. New York: Zone Books.

Dean, M. (2015) The Malthus Effect: Population and the Liberal Government of Life Economy and Society, 44 (1), 18-39.

Deutscher, P. (2012) Foucault's History of Sexuality I: Re-reading its Reproduction. Theory, Culture \& Society, 21 (1), 119-137. 
Dilts, A. (2014) Punishment and Inclusion: Race, Membership, and the Limits of American Liberalism. New York: Fordham University Press.

Easterlin, R. A. (1966) On the Relation of Economic Factors to Recent and Projected Fertility Changes. Demography, 3 (1), 131-153.

Easterlin, R. A., Pollak, R. A. \& Wachter, M. L. (1980) Toward a More General Economic Model of Fertility Determination. In R. A. Easterlin (Ed.), Population and Economic Change in Developing Countries (pp. 81-150). Chicago: Chicago University Press.

Esping-Andersen, G. \& Billari, F. C. (2015) Re-theorizing Family Demographics. Population and Development Review, 41 (1), 1-31.

Feher, M. (2009) Self-Appreciation; or, The Aspirations of Human Capital' Public Culture, 21 (1), 21-41.

Folbre, N. (1983) Of Patriarchy Born: The Political Economy of Fertility Decisions. Feminist Studies, $9(2), 261-284$.

Foucault, M. (1981) The History of Sexuality Volume 1: Will to Knowledge. London: Penguin.

Foucault, M. (2008) The Birth of Biopolitics: Lectures at the Collège de France 1978-1979. Basingstoke. Palgrave Macmillan.

Freedman, R \& Coombs, L. (1966) Economic Considerations in Family Growth Decisions. Population Studies 20 (2), 197-222.

Harcourt, B. E. (2011) The Illusion of Free Markets. Cambridge: Harvard University Press.

Joronen, M. (2013) Conceptualising New Modes of State Governmentality: Power, Violence and the Ontological Mono-Politics of Neoliberalism. Geopolitics, 18 (2), 356-370.

Koffman, O. and Gill, R. (2013) 'The revolution will be led by a 12-year-old girl': Girl power and global biopolitics’ Feminist Review, 105 (1), 83-102.

Lee, R. (2015) Becker and the Demographic Transition. Journal of Demographic Economics, 81 (1), 67-74.

Leibenstein, H. (1974) An Interpretation of the Economic Theory of Fertility: Promising Path or Blind Alley? Journal of Economic Literature, 12 (2), 457-479.

Lemke, T. (2001) 'The birth of biopolitics': Michel Foucault's lecture at the Collège de France on neo-liberal governmentality Economy and Society, 30 (2), 190-207. 
Lemke, T. (2011) Biopolitics: An Advanced Introduction. New York: New York University Press.

Lettow, S. (2015) Population, Race, and Gender: On the Genealogy of the Modern Politics of Reproduction. Distinktion: Journal of Social Theory, 16 (3), 267-282.

Mavelli, L. (2017) Governing the Resilience of Neoliberalism through Biopolitics. European Journal of International Relations, 23 (3), 489-512.

May, T. and McWhorter L. (2015) Who's Being Disciplined Now? Operations of Power in a Neoliberal World. In V. W. Cisney \& N. Morar (Eds), Biopower: Foucault and Beyond (pp. 245258). Chicago: University of Chicago Press.

McWhorter, L. (2010) Darwin's Invisible Hand: Feminism, Reprogenetics, and Foucault's Analysis of Neoliberalism. The Southern Journal of Philosophy, 48, 43-63.

Millei, Z. and Joronen, M. (2016) The (bio)politicization of neuroscience in Australian early years policies. Journal of Education Policy, 34 (1), 389-404.

Mincer, J. (1962) 'Labor Force Participation of Married Women: A Study of Labour Supply. In H. G. Lewis (Ed.), Aspects of Labor Economics (pp. 63-105). Princeton: Princeton University Press.

Mincer, J. and Polachek, S. (1974) Family Investments in Human Capital: Earnings of Women. In T. W. Schultz (Ed.), Economics of the Family: Marriage, Children, and Human Capital (pp. 397-431). Chicago: Chicago University Press.

Murphy, M. (2017) The Economization of Life. Durham: Duke University Press.

Namboodin, N. K. (1972) Some Observations on the Economic Framework for Fertility Analysis. Population Studies, 26 (2), 185-206.

Newheiser, D. (2016) Foucault, Gary Becker and the Critique of Neoliberalism. Theory, Culture \& Society, 33 (5), 3-21.

Nicholson, L. (2008) Identity Before Identity Politics. Cambridge: Cambridge University Press.

Paltrinieri, L. (2017) Biopolitics in the Twenty-First Century: The Malthus-Marx Debate and the Human Capital Issue. In P. Bonditti, D. Bigo \& F. Gros (Eds), Foucault and the Modern International (pp. 239-259). Basinstoke: Palgrave.

Peck, J. (2010) Constructions of Neoliberal Reason. Oxford: Oxford University Press.

Pollak, R. A. (2003) Gary Becker's Contributions to Family and Household Economics. Review of Economics of the Household, 1 (1), 111-141. 
Porter, T. M. The Rise of Statistical Thinking, 1820-1900. Princeton: Princeton University Press.

Repo, J. (2013) The Life Function: The Biopolitics of Sexuality and Race Revisited. Theory and Event 16 (3). Available at: https://muse.jhu.edu/article/520029 (accessed 15 July 2016).

Repo, J. (2016) Gender Equality as Neoliberal Governmentality in a Neoliberal European Union Social Politics, 23 (2), 307-328.

Roberts, D. (1997) Killing the Black Body: Race, Reproduction and the Meaning of Liberty. New York: Vintage.

Roberts, A. (2015) The Political Economy of 'Transnational Business Feminism'. International Feminist Journal of Politics, 17 (2), 209-231.

Rose, N. and Miller, P. (1990) ‘Governing Economic Life’ Economy and Society 19 (1), 1-31.

Royal Swedish Academy of Sciences (1992) Press Release: The Sveriges Riksbank Prize in Economic Sciences in Memory of Alfred Nobel 1992. Available at: http://www.nobelprize.org/nobel_prizes/economic-sciences/laureates/1992/press.html (accessed 5 July 2016).

Sanderson, W. C. (1976) On Two Schools of the Economics of Fertility. Population and Development Review, 2 (3-4), 469-477.

Schultz, S. (2015) Reproducing the Nation: The New German Population Policy and the Concept of Demographization. Distinktion: Journal of Social Theory, 16 (3), 337-361.

Schultz, T. P. (1994) Human Capital, Family Planning, and Their Effects on Population Growth. The American Eocnomic Review, 84 (2): 255-260.

Schultz, T. P. (ed) (1995) Investment in Women's Human Capital. Chicago: Chicago University Press.

Schultz, T. W. (1961) Investment in Human Capital. The American Economic Review, 51 (1), 1-17.

Schultz, T. W. (1973) The Value of Children: An Economic Perspective. Journal of Political Economy, 81 (2), S2-13.

Schultz, T. W. (ed) (1974) Economics of the Family: Marriage, Children and Human Capital. Chicago: University of Chicago Press.

Schultz, T. W. (1982) Investing in People: The Economics of Population Quality. Berkeley: University of California Press. 
Shain, F. (2013) 'The Girl Effect': Exploring Narratives of Gendered Impacts and Opportunities in Neoliberal Development', Sociological Research Online. 18 (2), 1-11.

Spengler, J. (1966) Values and Fertility Analysis. Demography, 3 (1), 109-130.

Stoler, A. L. (1995) Race and the Education of Desire. Durham: Duke University Press.

United Nations (1995) Report on the International Conference on Population and Development. New York: United Nations.

Van Horn, R., Mirowski, P. and Stapleford, T. A. (2013) Building Chicago Economics: New Perspectives on the History of America's Most Powerful Economics Program. Cambridge: Cambridge University Press.

Wacquant, L. (2004) Punishing the Poor: The Neoliberal Government of Social Insecurity. Durham: Duke University Press.

Wilson, K. (2015) Towards a Radical Reappropriation: Gender, Development and Neoliberal Feminism. Development and Change 46 (4), 803-832.

Winnubst, S. (2013) The Missing Link: Homo Economicus (Reading Foucault and Bataille Together). In C. Falzon, T. O’Leary \& J. Sawicki (Eds), A Companion to Foucault (pp. 454-471). Oxford: WileyBlackwell. 